\title{
Improved Maize Growth in Condition Controlled by PGPR Inoculation on Ferruginous Soil in Central Benin
}

\author{
Olaréwadjou Amogou', Nadège Adoukè Agbodjato1, Gustave Dagbénonbakin², \\ Pacôme Agossou Noumavo1,3, Haziz Sina1, Assogba Abado Sylvestre', Marcel Yévèdo Adoko1, \\ Martial Nounagnon' ${ }^{1}$, Romain Glèlè Kakaï ${ }^{4}$, Adolphe Adjanohoun ${ }^{2}$, Lamine Baba-Moussa ${ }^{1 *}$
}

\begin{abstract}
${ }^{1}$ Laboratoire de Biologie et de Typage Moléculaire en Microbiologie, Département de Biochimie et de Biologie Cellulaire, Faculté des Sciences et Techniques, Université d'Abomey-Calavi, Cotonou, Bénin

${ }^{2}$ Centre de Recherches Agricoles d'Agonkanmey, Institut National des Recherches Agricoles du Bénin, Cotonou, Bénin

${ }^{3}$ Laboratoire de Microbiologie et des Technologies Alimentaires, Département de Biologie Végétale, Faculté des Sciences et Techniques, Université d'Abomey-Calavi, Cotonou, Bénin

${ }^{4}$ Laboratoire de Biomathématique et d'Estimation Forestière, Faculty of Agronomic Sciences, University of Abomey-Calavi, Cotonou, Bénin

Email: *laminesaid@yahoo.fr
\end{abstract}

How to cite this paper: Amogou, O., Agbodjato, N.A., Dagbénonbakin, G., Noumavo, P.A., Sina, H., Sylvestre, A.A., Adoko, M.Y., Nounagnon, M., Kakaï, R.G., Adjanohoun, A. and Baba-Moussa, L. (2019) Improved Maize Growth in Condition Controlled by PGPR Inoculation on Ferruginous Soil in Central Benin. Food and Nutrition Sciences, 10, 1433-1451. https://doi.org/10.4236/fns.2019.1012102

Received: November 16, 2019 Accepted: December 28, 2019 Published: December 31, 2019

Copyright $\odot 2019$ by author(s) and Scientific Research Publishing Inc. This work is licensed under the Creative Commons Attribution International License (CC BY 4.0).

http://creativecommons.org/licenses/by/4.0/

(c) (i) Open Access

\begin{abstract}
The use of microbial technologies in agriculture is rapidly expanding with the discovery of new bacterial strains effective in improving plant growth. In this study, we tested and highlighted the efficacy of PGPR (Plant Growth Promoting Rhizobacteria) alone or in a consortium on maize growth. For this purpose, a greenhouse experiment was carried out in pots containing sterilized ferruginous soil for 30 days. The corn seeds of the EVDT 97 SRT C1 variety were inoculated with bacterial suspensions of concentration $10^{8}$ $\mathrm{UFC} / \mathrm{ml}$. The experimental device was a random block of 16 three-repeat treatments. The incidence of PGPR inoculated strains is assessed on the biomass growth and yield parameters of maize. At the end of the trial, the results showed that inoculation stimulated plant growth and development and resulted in a significant increase in the height, diameter at the collar, leaf surface and dry weight of aerial biomass of $20.15 \%, 21 \%, 32.77 \%$ and $37.73 \%$ respectively compared to controls, especially in corn plants inoculated with $B$. thurengiensis $+B$. panthéthonicus $+S$. marcescens and Pseudomonas cichorii + Pseudomonas putida + Pseudomonas syringae. These results show the potential of using these rhizobacteria as biological inoculants to improve maize productivity in Benin.
\end{abstract}




\section{Keywords}

PGPR, PGPR, Inoculation, Growth, Biomass, Ferruginous Soil

\section{Introduction}

Some bacteria that live in the rhizosphere define how the volume of soil influenced by the roots has the ability to promote plant growth [1] [2]. These microorganisms referred as PGPR drew attention to the need to reduce chemicals particularly in the context of sustainable agriculture and environmental protection [3]. PGPRs influence plant health and productivity through a variety of mechanisms that involve mineral solubilization, nitrogen fixation, phytohormone synthesis, hydrolytic enzyme synthesis and balance modulation plant hormone by deamination of the ethylene precursor

1-aminocyclopropane-1-carboxylate (ACC) [4] [5]. These rhizobacteria can improve the elongation and branching of the root system which promotes the absorption of water and minerals from the soil to the host plant including wheat, barley, corn and rice that are necessary for plant survival [6]. The benefits of PGPR inoculation on plant growth and productivity are well documented and have been correlated with phytohormone production and higher nutrient intake [7] [8] [9]. Various species of PGPR have been considered PGPR to stimulate plant growth and some of them marketed in recent years belong to the genera Pseudomonas, Azospirillum, Azotobacter, Bacillus, Enterobacter, Rhizobium, Mycobacterium, Enterobacter, Caulobacter, Serratia, Flavobacterium, Actinobacteria sp. [10] [11].

Maize is a staple crop in Benin but soils are poor and inappropriate use of mineral fertilizers prevents producers from achieving the potential yield of this crop. Several research studies have reported that the excessive use of chemical fertilizers in agronomic systems aiming at improving yield, is less efficient in terms of stabilizing chemical elements that are quickly leached just after their application at ground level [12] [13]. This represents a deficit of absorption and nutritional assimilation in plants.

In Benin, the phenomenon of soil degradation is increasing especially in central regions dominated by ferruginous soils. This contributes to the depletion of organic matter in the soil as well as the nutrients essential for plant development [14]. The role of PGPRs in resolving several constraints such as soil degradation, water stress, and declining soil fertility that limit agricultural production has been widely proven [15]. The use of plant growth-promoting bacteria (PGPR) can be a promising alternative that can reduce the application of chemicals and improve crop yields and plant health [16] [17] [18]. For example, [19] has shown that PGPRs can increase nutrient bioavailability in the rhizosphere. They fix nutrients and prevent them from washing. In the work undertaken [20], the improvement in wheat yield was attributed to the co-inoculation of Bacillus thuringiensis and Serratia sp. Similarly, [21] [22] noted that inoculation of corn 
seeds with strains of Bacillus polymyxa, Pseudomonas alcaligenes and Actinomycetes sp. (O19-AHB12) significantly improved the dry weight of maize plants by $19 \%$ to $52 \%$, total maize biomass by $38 \%$ and the weight of 1000 corn seeds by $74.72 \%$ compared to controls. To date, little work has been done in Benin on the use of PGPRs to improve maize growth and yield. The objective of this study is to investigate the effects of nine (09) isolated rhizobacteria (PGPR) identified in central and northern Benin on the growth of greenhouse maize on ferruginous soil in central Benin.

\section{Material and Methods}

\subsection{Material}

- Corn seeds

The maize seeds used are those of the variety EVDT 97 STR C1 from the South Agricultural Research Centre (CRA-South) of the National Institute for Agricultural Research in Benin (INRAB). This variety is resistant to American rust, streak, helminthosporiosis, curvulariosis and drought [23].

- Provenance and characteristics of PGPR strains

Nine (9) strains of PGPR namely Bacillus polymyxa, Bacillus anthracis, Bacillus thuringiensis, Bacillus circulans, Bacillus panthothenicus, Pseudomona cichorii, Pseudomona putida, Pseudomona syringae and Serratiamarcescens were used. These strains were isolated and characterized from the corn rhizosphere of the various agroecological zones of Central and Northern Benin by [24] and stored at $-20^{\circ} \mathrm{C}$ in Muller Hinton broth with glycerol (10\%) laboratory of Biology and Molecular Typing in Microbiology at the University of Abomey-Calavi. The majority of strains show major fertilization and phytostimulation activities such as phosphate solubilization and acetic indole acid (IAA) production [25].

\subsection{Methods}

\subsubsection{Preparing the PGPR Inoculum}

The method described by Guiraud and Galzy, 1994 was used to rejuvenate by transplanting the three (3) strains of Pseudomonas on King B medium. The Bacillus and Serratia strains were revived on Nutritive Agar [26] [27]. The inoculum of each PGPR was obtained by culture in a nutrient medium (liquid HD) for 24 hours at $30^{\circ} \mathrm{C}$. The method described by [28] allowed us to adjust bacterial cultures to a concentration of approximately $1 \times 10^{8} \mathrm{UFC} / \mathrm{ml}$ (OD 0.45 to 610 $\mathrm{nm}$ ) with a spectrophotometer 24 hours after incubation.

\subsubsection{Experimental Device}

The device adopted was a complete random block comprising sixteen (16) treatments with three (03) repetitions. Treatments have been defined as T1: Bacteria-Free Control, T2: Bacillus polymysa, T3: Bacillus anthracis, T4: Bacillus circulans, T5: Bacillus thuringiensis, T6: Bacillus panthothenicus, T7: Pseudomonas cichorii, T8: Pseudomonas putida, T9: Pseudomonas syringae, T10: Serratiamarcescens, T11: Bacillus polymys, Bacillus anthracis, Bacillus. circulans, Ba- 
cillus thuringiensis, Bacillus panthothenicus, T12: Bacillus thuringiensis, Bacillus panthothenicus, Serratia marcescens, T13: Pseudomonas cichorii, Pseudomonas putida, Pseudomonas syringae, T14: Pseudomonas putida, Serratiamarcescens, T15: Pseudomonas putidai, Bacillus thuringiensis, T16: Pseudomonas putida, Bacillus thuringiensis, Serratia marcescens.

\subsubsection{Processing the Substrate and Filling the Jars}

The soil used consisted of depleted tropical ferruginous composite soil from the experimental site of the Agricultural Research Centre (CRA-Centre) in Gobé. This substrate is removed at a depth of 0 to $20 \mathrm{~cm}$ using a graduated shovel spade and is dried in the sun. It is then sifted to $2 \mathrm{~mm}$ and then doubly sterilized at $120^{\circ} \mathrm{C}$ for 20 minutes at a 24 -hour interval [29]. Then, $3 \mathrm{~kg}$ of the sterilized soil was weighed and distributed in each pot.

\subsubsection{Description of the Chemical Characteristics of the Soil Used}

The soil was analyzed in a previous study published in 2017 [30]. The data is in Table 1 . This soil was moderately acidic, with a $\mathrm{pH}$ (water) of 6.5 . The analysis also showed that the nitrogen $(0.076 \%)$, phosphorus $(5 \mathrm{ppm})$, potassium $(0.16$ meq)/100g) levels are very low. The sum of the exchangeable bases (3.66 $\mathrm{meq} / 100 \mathrm{~g}$ ) is very small. On the other hand, the cationic exchange capacity ( 8 $\mathrm{meq} / 100 \mathrm{~g}$ ) was average. These chemical properties reflect limited fertility of the study soil due to its low reserves of major nutrients (N, P and K) recorded.

\subsubsection{Semi, Inoculation and Pot Maintenance}

The pots were arranged inside the greenhouse and then watered at 2/9th of their maximum water retention capacity (CMR) 24 hours before sowing [31]. After opening the hole, two (02) seeds were deposited per pot and then inoculated with $10 \mathrm{ml}$ of suspension of each bacterial strain of concentration $10^{8} \mathrm{UFC} / \mathrm{ml}$. The hole was immediately closed. A quantity of $500 \mathrm{ml}$ water, or 1/9th of the soil's maximum water retention capacity (CRM), was brought to the plants every 48 hours after seed germination. Thinning to one plant per pot was performed one week after germination. The experiment was conducted in May 2019 under a greenhouse located within the grounds of the University of Abomeycalavi (West Africa, Republic of Benin) at an altitude of $22 \mathrm{~m}$ between latitude $6-258^{\prime} \mathrm{N}$ and longitude $2-20^{\prime} \mathrm{E}$. The average temperature inside the greenhouse is $25.1^{\circ} \mathrm{C}$ and $27.23^{\circ} \mathrm{C}$ during the trial period.

\subsubsection{Data Collection}

Morphometric measurements were made 7 days after sowing. These morphometric

Table 1. Chemical characteristics of the soil.

\begin{tabular}{ccccccc}
\hline $\begin{array}{c}\mathrm{pH} \\
\text { (water) }\end{array}$ & $\begin{array}{c}\mathrm{Pa} \\
(\mathrm{ppm})\end{array}$ & $\begin{array}{c}\text { Nitrog } \\
(\%)\end{array}$ & $\begin{array}{c}\text { MO } \\
(\%)\end{array}$ & $\begin{array}{c}\text { K-ech } \\
(\mathrm{meq} / 100 \mathrm{~g})\end{array}$ & $\begin{array}{c}\text { Exchangeable bases } \\
(\mathrm{meq} / 100 \mathrm{~g})\end{array}$ & $\begin{array}{c}\mathrm{CEC} \\
(\mathrm{meq} / 100 \mathrm{~g})\end{array}$ \\
\hline 6.5 & 5 & 0.076 & 1.16 & 0.16 & 3.66 & 8
\end{tabular}

MO: organic matter; $\mathrm{Pa}(\mathrm{ppm})$ : assimilable phosphorus; K-ech: exchangeable potassium; CEC: ability to exchange cationique, ppm: percentage per thousand; meq: milliequivalent. 
characteristics were the height and diameter at the collar of the plants estimated respectively using a ruler tape and the caliper at the slide sliding every 96 hours for 30 days. At that time, the leaf surface of the plants was calculated according to the method described by [32] using the measurement of the length and width of the last two leaves ligulate of the plants. In addition, the young corn plants were gently dug up and the roots were immersed in a large bowl of tap water to rid them of soil particles. The freshly weighed biomass was sun-dried at $100^{\circ} \mathrm{C}$ for 72 hours to determine the dry weight of aerial and underground biomass.

\subsubsection{Statistical Analysis}

The Hierarchic Classification on Main Components (HCPC) preceded by a Main Component Analysis (ACP) was conducted to identify the pattern of discrimination caused by the effect of the PGPR and their combination on the growth and productivity parameters. The combination of these two consecutive multivariate analyzes is useful for showing the pattern across the data set [33]. The different classes obtained were described using descriptive statistics (mean, standard deviation). These multivariate analyzes were performed in the R 3.6.0 software [34] and required the use of the FctoMine $\mathrm{R}$ and factoextra packages. Within each group, the effect of PGPR and their combination on neck height and diameter was assessed for each parameter by fitting a linear mixed effects model to longitudinal data. In each model, the groups obtained were considered as fixed factors and time as a random factor. Adjusted averages were also calculated to represent the evolutionary trends of each growth parameter in each group. These analyzes were done with the $\mathrm{R}$ software using the packages nlme (for the fit of the model), lsmeans (for the computation of the adjusted averages), and ggplot2 (for the representation of the curves). The impact of PGPR and their combination on leaf area and plant yield parameters were assessed using an analysis of variance after verification of normality and homoscedasticity of the data respectively by Ryan-Joiner and Levene tests [35]. Post hoc or multiple comparison tests (SNK test) were performed to assess the statistical differences in averages when anova results are significant. Adjusted averages were also calculated to represent the averages of each parameter for each group. The car and lsmeans packages were respectively used to perform the anova, and the calculation of the adjusted averages.

\section{Results}

\subsection{Identifying Homogeneous Groups of Treatments}

The ACP carried out on the different parameters of plant growth and yield shows that the first two axes retain $78.67 \%$ of the total variance. All growth parameters and yield parameters are strongly correlated with axis 1 and only the BSS variable (dry underground biomass) which is strongly correlated with axis 2 (Figure 1(a)).

The hierarchical classification of main components (HCPC) applied to the averages of the measured variables allowed the definition of four treatment 


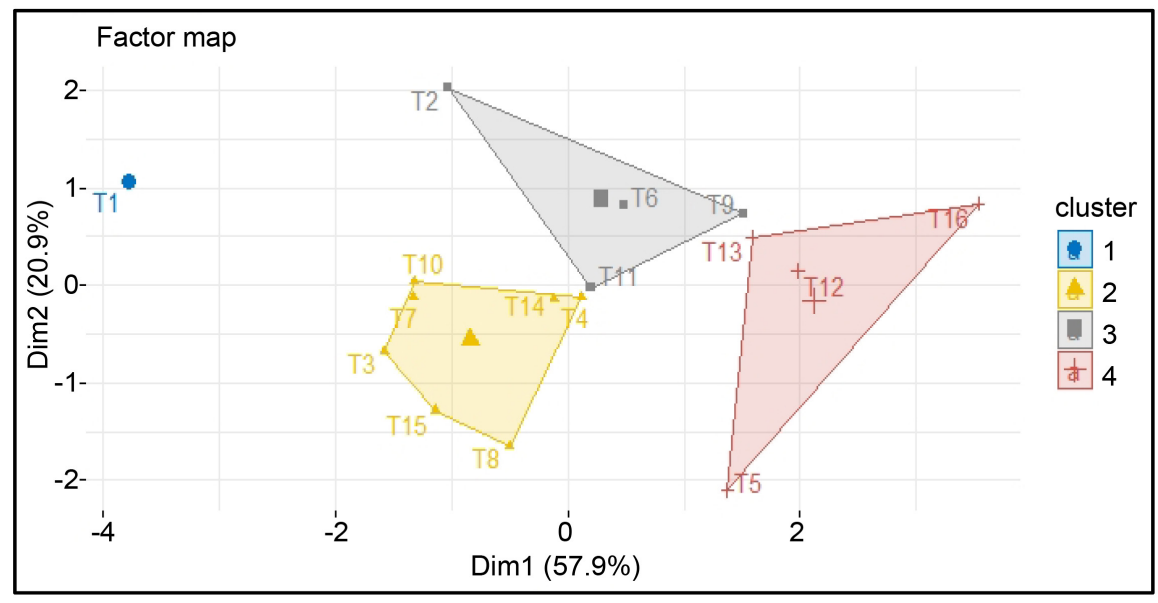

(a)

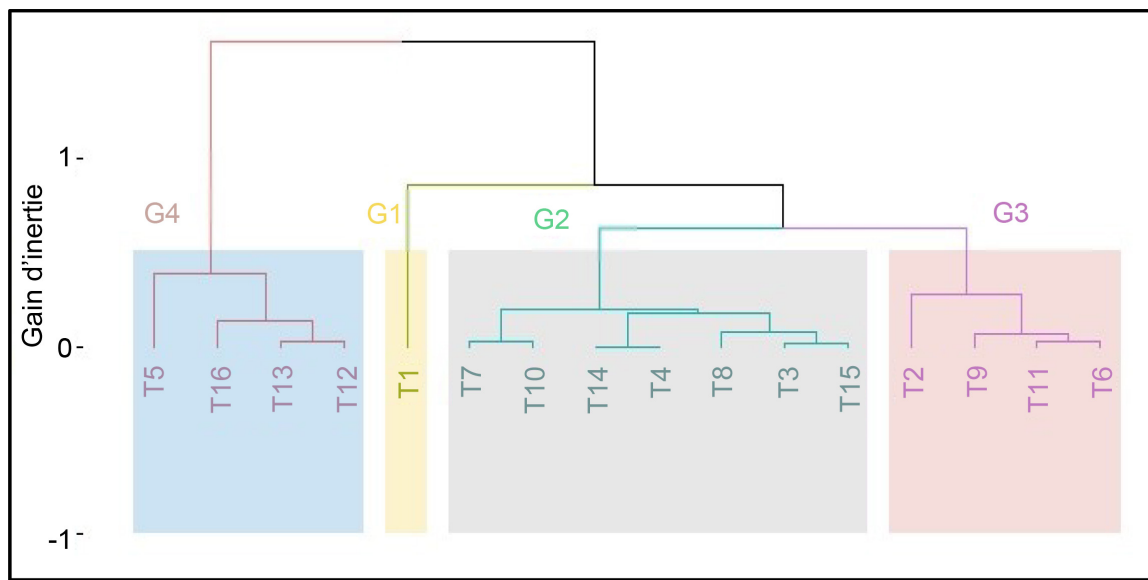

(b)

Figure 1. (a) ACP result showing different clusters based on the links between the measured variables; (b) Dendrogram of classes of different treatments (PGPR and combination) applied to plants.

groups (Figure 1(b)) discriminated against by the height, neck diameter and underground dry biomass variables. These homogeneous groups (G1, G2, G3 and G4) obtained were used to analyze the effect of PGPR and their combination on the growth and yield parameters of maize plants.

The first group (G1) consists of a single treatment, the control (T1). The second group (G2) consists of B. anthracis (T3), B. circulens (T4), P. putida (T8), P. cichorii (T7), S. marcescens (T10), P. Putida, S. marcescens (T14) and $P$. Putida, B. Thuringiensis (T15). Four treatments including a combination of PGPR are classified as Group 3 (G3). These are B. polymyxa (T2), P. syringae (T9), B. panthothenicus (T6) and B. polymyxa, B. anthracis, B. circulatens, $B$. thuringiensis, $B$. panthethonicus (T11). Group 4 (G4) consists of $B$. thuringiensis (T5), B. thuringiensis, B. panthethonicus, S. marcescens (T12), P. cichorii, P. putida, $P$. syringae (T13) and $P$. putida, $B$. thuringiensis, $S$. marcesens (T16). It should be noted that the treatments constituting group 4 are mostly combinations of several PGPRs. 


\subsection{Effect of PGPRs and Their Combination on the Growth Parameters of Corn Plants}

\subsubsection{Effect of PGPRs and Their Combination on the Height of Corn Plants}

Based on the results of the mixed-effect linear model (Table 2), it appears that time has a significant effect on plant height growth (p-value $<0.0001$ ). However, the treatment (groups) ( $\mathrm{p}$-value $=0.62)$ and the interaction between time and treatment ( $p$-value $=0.45$ ) are not significant, indicating that the variations observed over time do not at first depend on treatment.

The curve (Figure 2) shows the impact of treatment groups on plant height. Plants subjected to the effect of the G1 group (control treatment) are characterized by an average height of $26.4 \mathrm{~cm}$. This is the lowest height performance recorded during the study. On the other hand, plants that benefited from G4 treatments had the best average heights $(31.72 \pm 0.28 \mathrm{~cm})$ an improvement of

Table 2. Mixed-effect linear model results applied to plant height averages.

\begin{tabular}{ccccc}
\hline & numDF & denDF & F-value & p-value \\
\hline (Intercept) & 1 & 326 & 3824.441 & $<0.0001$ \\
Time & $\mathbf{1}$ & $\mathbf{3 2 6}$ & $\mathbf{2 2 0 9 . 7 3 2}$ & $<0.0001$ \\
Groups & 3 & 326 & 0.598 & 0.6166 \\
Time: Groups & 3 & 326 & 0.870 & 0.4567 \\
\hline
\end{tabular}

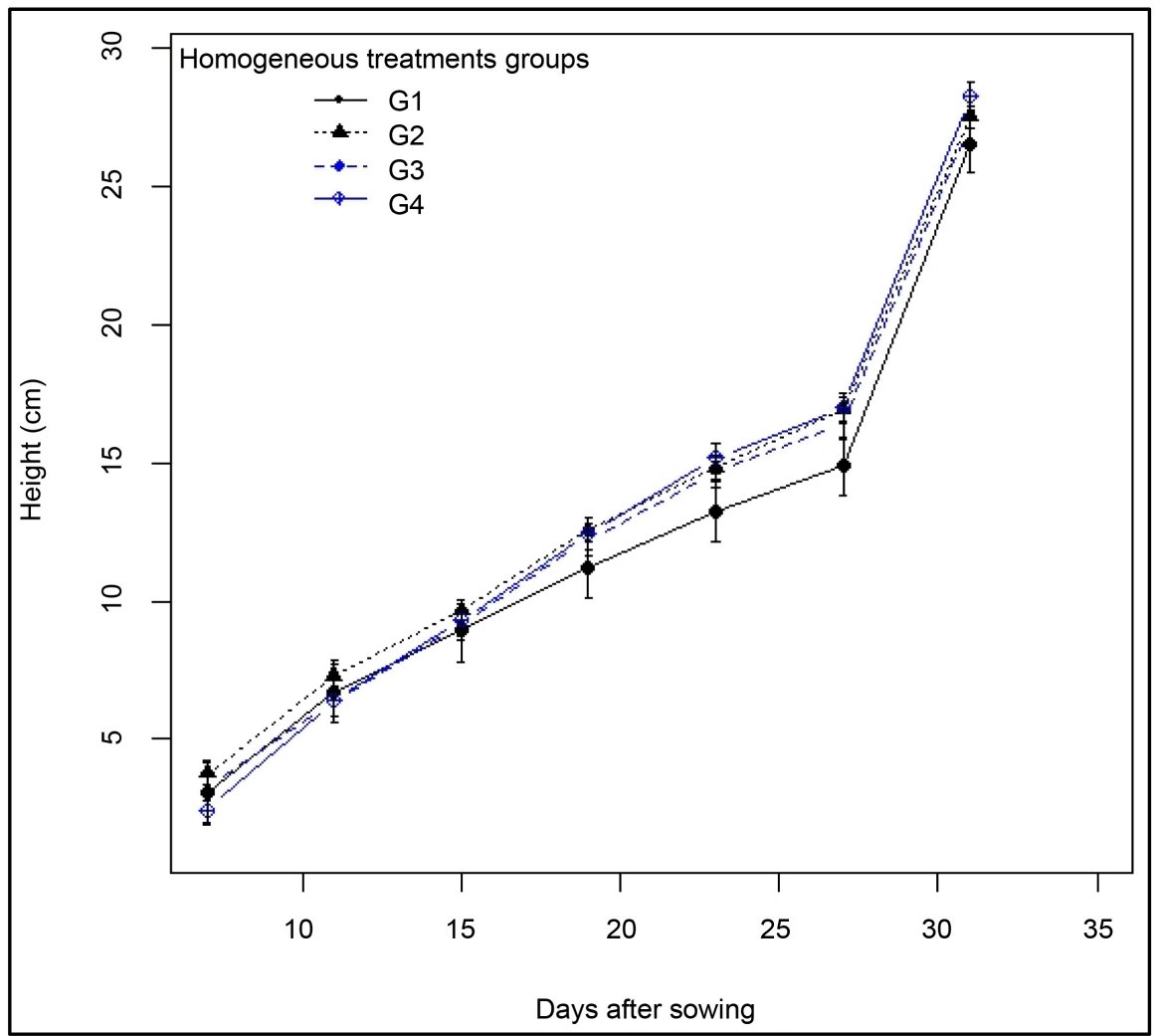

Figure 2. Evolutionary trend in the height of corn plants by groups of rhizobacteria. 
$20.15 \%$ compared to the G1 group (control). The minimum and maximum heights of this group (G4) were $31.33 \mathrm{~cm}$ and $31.93 \mathrm{~cm}$ respectively. At the end of the trial, the group 2 (G2) plants had a minimum height of $26.83 \mathrm{~cm}$ with a peak of $30.03 \mathrm{~cm}$. For group 3, the minimum plant size was $27.83 \mathrm{~cm}$ while the highest recorded height was $29.16 \mathrm{~cm}$. It should be noted that group 2 and group 3 (G3) treatments had similar effects on plant height after 30 days of sowing. The average values obtained were $28.48 \pm 1.34 \mathrm{~cm}$ and $28.44 \pm 0.58 \mathrm{~cm}$ respectively. This means that the height of the group 4 plants increased by about $12.11 \%$ compared to that of groups 2 and 3 .

\subsubsection{Effect of PGPR and Their Combination on the Diameter at the Collar of Corn Plants}

Analysis of mixed-effect variance (Table 3) applied to plant collar diameter averages shows that time has a significant effect on the growth of plant collar diameter ( $\mathrm{p}$-value $<0.0001)$. The treatment (groups) ( $\mathrm{p}$-value $=0.02$ ) and the interaction between time and treatment $(\mathrm{p}$-value $<0.01)$ are also significant, indicating that the variations observed over time depend on treatment (group). The evolution curves of the diameter at the plant collar vary significantly from one collection period to another than from one treatment to another (Figure 3 ). In

Table 3. Mixed-effect linear model results applied to plant collar diameter averages.

\begin{tabular}{ccccc}
\hline & numDF & denDF & F-value & p-value \\
\hline (Intercept) & 1 & 326 & 10320.943 & $<0.0001$ \\
Time & 1 & 326 & 1602.311 & $<0.0001$ \\
Groups & 3 & 326 & 3.103 & 0.0268 \\
Time: Groups & 3 & 326 & 4.476 & 0.0043 \\
\hline
\end{tabular}

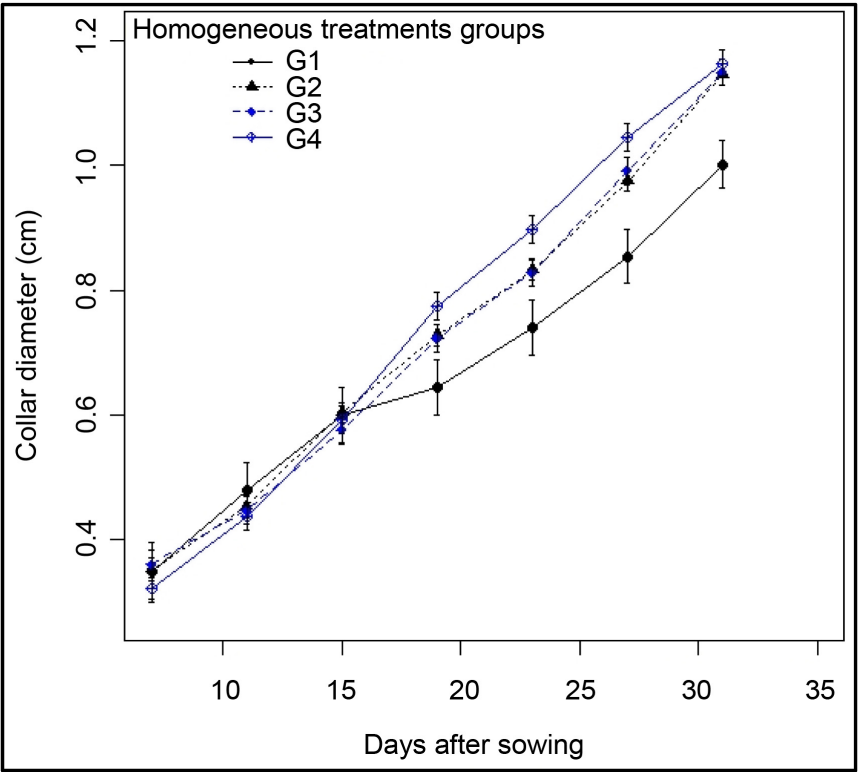

Figure 3. Evolutionary diameter trends at corn plant collars by treatment groups. 
fact, non-inoculated plants representing group 1 (G1) members had the best diameters at the collar from the 7th to the 14th days after sowing. From this period, plants inoculated with group 4 (G4) rhizobacteria took over until the end of the test with an average diameter value at the collar of $1.21 \pm 0.04 \mathrm{~cm}$ versus 1 $\mathrm{cm}$ for group 1 (G1) plants. This indicates that group 4 (G4) rhizobacteria induced a $21 \%$ increase over the control. Plants subject to the effect of the G3 group and group 2 give your intermediate tendencies between group 1 (G1) and group 4 (G4). The average collar diameter of $1.18 \pm 0.03 \mathrm{~cm}$ was recorded in plants in these two groups (G2 and G3).

\subsubsection{Effect of PGPR and Their Combination on Leaf Surface of Corn Plants}

Figure 4 illustrates the effect of rhizobacteria inoculation by group of treatments on the leaf surface of plants. Measuring the leaf surface of plants shows a visible positive effect (Table 4 ) of inoculation by treatments (B. thuringiensis, B. thuringiensis, $B$. panthethonicus, $S$. marcescens, $P$. cichorii, $P$. putida, $P$. syringae and $P$. putida, B. thuringiensis $S$. marcesens) of group 4 followed by group 3 rhizobacteria with an average leaf area of $190.18 \pm 19.90 \mathrm{~m}^{2}$ and $173.74 \pm 15.09$ $\mathrm{m}^{2}$ respectively. The performance of group 4 rhizobacteria improved the leaf surface of corn plants by more than $32.77 \%$ and $9.46 \%$, respectively, compared

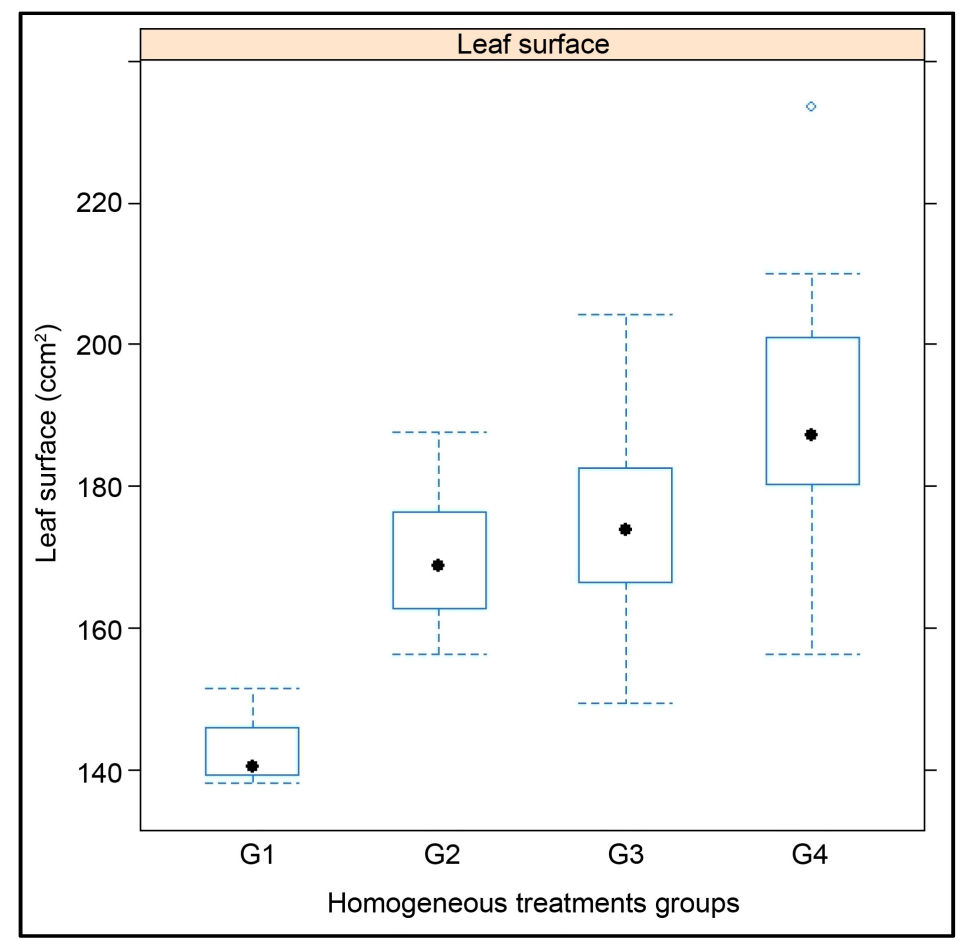

Figure 4. Effect of treatments by group on plant leaf surface.

Table 4. Results analysis of variance applied to averages of plant leaf surface.

\begin{tabular}{lcccccc}
\hline & Df & Sum Sq & Mean Sq & F value & $\operatorname{Pr}(>$ F $)$ & \\
\hline Groups & 3 & 6522.1 & 2174.02 & 11.255 & $1.32 \mathrm{e}-05$ & $* * *$ \\
\hline
\end{tabular}


to the control and group $3(\mathrm{G} 3)$ plants.

\subsubsection{Effect of PMPRs and Their Combination on the Biomass Yield Parameters of Corn Plants}

In Figure 1, group $4(\mathrm{G} 4)$ rhizobacteria inoculated plants produced the largest dry aerial biomass, an increase of $30.73 \%$ over the control. Based on the results of the variance analysis (Table 5), there was a significant difference $(\mathrm{p}<0.001)$ between the different treatment groups. In addition, a highly significant improvement $(\mathrm{p}<0.001)$ was observed between the treatment groups on dry underground biomass of the plants (Table 6). The best productions $(3.42 \pm 0.42 \mathrm{~g})$ were recorded at the level of the plants of pin 3 (G3) followed by those of group 4 (G4) $(3.06 \pm 0.45 \mathrm{~g})$. Non-inoculated plants of group 1 (G1) were the least productive.

\section{Discussion}

Various research has focused on the assessment of rhizobacteria for their ability to induce improvements in growth and yield parameters on controlled cereals (Qaisrani et al., 2014) [36] (Karnwal, 2017) [37]. Based on the analysis of the data presented at the level of Figure 2, it is noted that the plants that benefited from the treatments $B$. thuringiensis, B. thurenthonicus, B. panthothenicus, $S$. marcescenss, $P$. cichorii, $P$. putida, $P$. syringae and $P$. putida, $B$. thuringiensis $S$. marcesens all in group 4 showed the best growth in height with an increase of $20.15 \%$ compared to control plants in the group 1 . The promoter effect of these treatments exceeds by $12.11 \%$ that induced by $B$. anthracis, B. circulens, $P$. putida, $P$. cichorii, S. marcescens, $P$. putida, $S$. marcescens and $P$. putida, B. thuringiensis du gropue 2 . It is the same for $B$. polymyxa, P. syringae, $B$. panthothenicus and B. polymyxa "B. anthracis" B. circulatens, B. thuringiensis B. panthethonicus classified in group 3 . The same trend was observed on the diameter at the collar of the plants. Indeed, the highest neck diameter values were obtained by group 4 rhizobacteria. These treatments resulted in a $21 \%$ improvement over the diameter at the collar of non-inoculated group 1 plants. Our experimental results are consistent with those of Noumavo et al. (2013) [38], which reported increases of $26.77 \%$ and $30.25 \%$ respectively on the diameter at the collar as well as on the height of the corn plants inoculated with the combination of $P$. fluorescens, $P$. putida versus the witness. In addition, the work of Emami et al. (2019)

Table 5. Results analysis of variance applied to dry aerial biomass produced by plants.

\begin{tabular}{lcccccc}
\hline & Df & Sum Sq & Mean Sq & F value & $\operatorname{Pr}(>\mathrm{F})$ & \\
\hline Groups & 3 & 9.740 & 3.2468 & 4.4621 & 0.008041 & $* *$ \\
\hline
\end{tabular}

Table 6. Results of variance analysis applied to dry underground biomass produced by plants.

\begin{tabular}{lcccccc}
\hline & Df & Sum Sq & Mean Sq & F value & $\operatorname{Pr}(>\mathrm{F})$ & \\
\hline Groups & 3 & 5.2194 & 1.73981 & 9.7649 & $4.675 \mathrm{e}-05$ & $* * *$ \\
\hline
\end{tabular}


[39] have recently demonstrated that co-inoculation of eight bacterial strains of different taxa (Pseudomonas, Bacillus, Stenotrophomonas, Serratia, Nocardia and Microbacterium) with several PGP traits allows for increased growth of plants than mono-inoculation. From an agronomic point of view, the diameter at the collar appears as a very important parameter for the plants. The more robust they are, the more they will be able to withstand the environmental conditions that have become increasingly difficult in recent years as a result of climate change (Duponnois et al., 2005) [40] (Biaou et Gnimadi, 2012) [41].

Among the parameters of agronomic interest is also the leaf surface used by researchers to measure the photosynthetic capacity of plants. In this study, inoculation of plants by rhizobacteria of different taxa had a highly beneficial effect on the leaf surface of the plants 30 days after sowing (Figure 4). The best leaf surfaces were recorded at the plant level both by mono-inoculation (B. thuringiensis) and by co-inoculation of group 4 rhizobacteria strains with an improvement of more than $32.77 \%$ over the control. Group 2 and 3 plants had leaves with an improvement of $21.29 \%$ and $17.92 \%$ respectively compared to non-inoculated plants. This means that the inoculation of group 4 rhizobacteria resulted in a leaf area gain of $11.48 \%$ and $14.85 \%$ respectively compared to the group 3 and group 2 plants. Such results were reported by Noumavo et al. (2013) [38] with inoculation of corn seeds on ferralitic soil in southern Benin. Other scientists have also observed increased plant height and leaf surface through inoculation with bacterial combinations (Govindappa et al., 2011) [28]. Increased growth was also recorded on other crops such as wheat (Salantur et al., 2006) [42], rice (Nandakumar et al., 2001) [43] and on tomatoes (Oluwambeet Kofoworola, 2016) [44] due to co-inoculation of rhizobacteria. Akhtar et al. (2018) [45] justify the broadest leaves carried by corn plants under the influence of rhizobacteria combinations by better development of the root system of the plants; this is conducive to better absorption not only of nutrients but also of water and therefore of better productivity.

In terms of biomass yield, the dry weight of the aerial and underground biomass of the plants measured during our harvest study was significantly improved with inoculation compared to control plants (Figure 5). The results of the variance analysis applied to the average weights at the level of each group indicated a significant effect (Table 5) and a highly significant effect (Table 6) respectively for dry air biomass and dry underground biomass. Indeed, plants treated with $B$. thuringiensis and other combinations of group 4 rhizobacteria induced the best weight of aerial biomass (5.53 - $1.02 \mathrm{~g})$ with an increase of $30.73 \%$ compared to the control. In contrast, the highest subterranean biomass dry weight (3.42 - $0.42 \mathrm{~g}$ ) was obtained with $B$. polymyxa, $P$. syringae, $B$. panthetonicus, and B. anthracis, B. circulans, B. thuringiensis, B. panthetonicus, $B$. polymyxa) in group 3 followed by group 3 treatments 4 . They induced an improvement rate of $26.19 \%$ and $12.91 \%$ respectively over the group 1 control plants. Similarly, Akhtar et al. (2018) [45] reported that the combination of 4 rhizobacteria (Bacillus megaterium, Pseudomonas aeruginosa, Serratia spp., and 


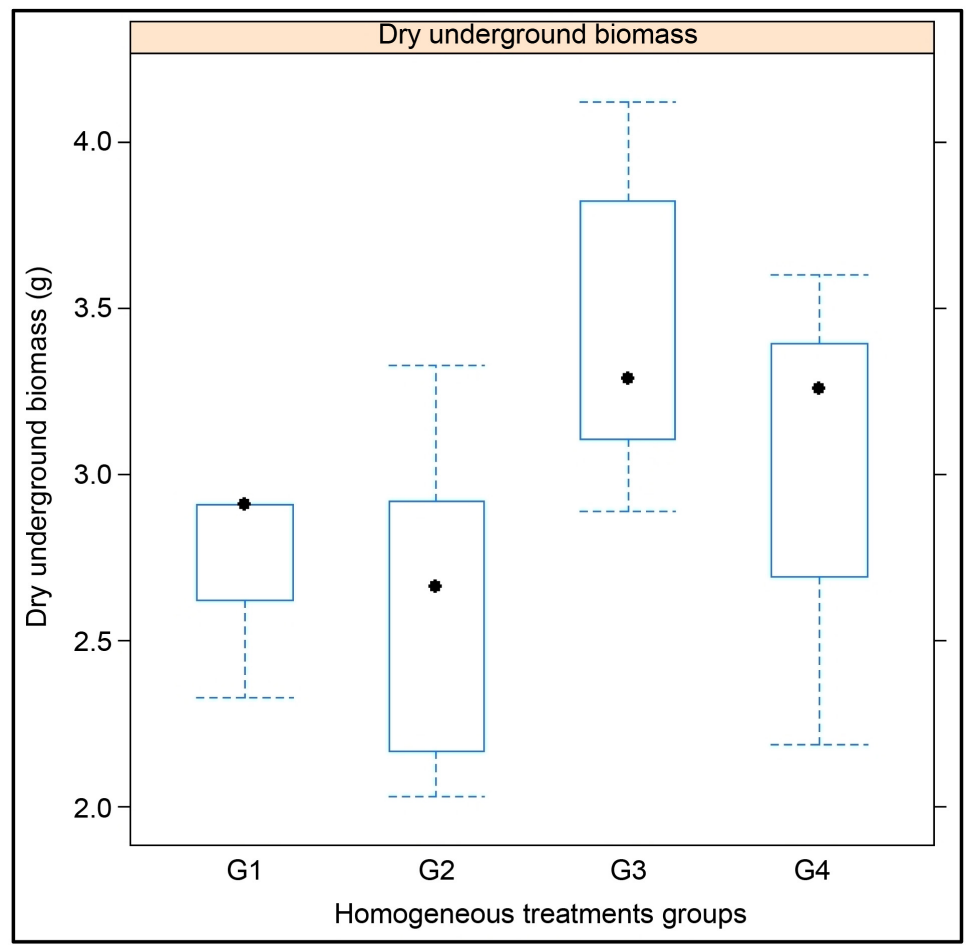

(a)

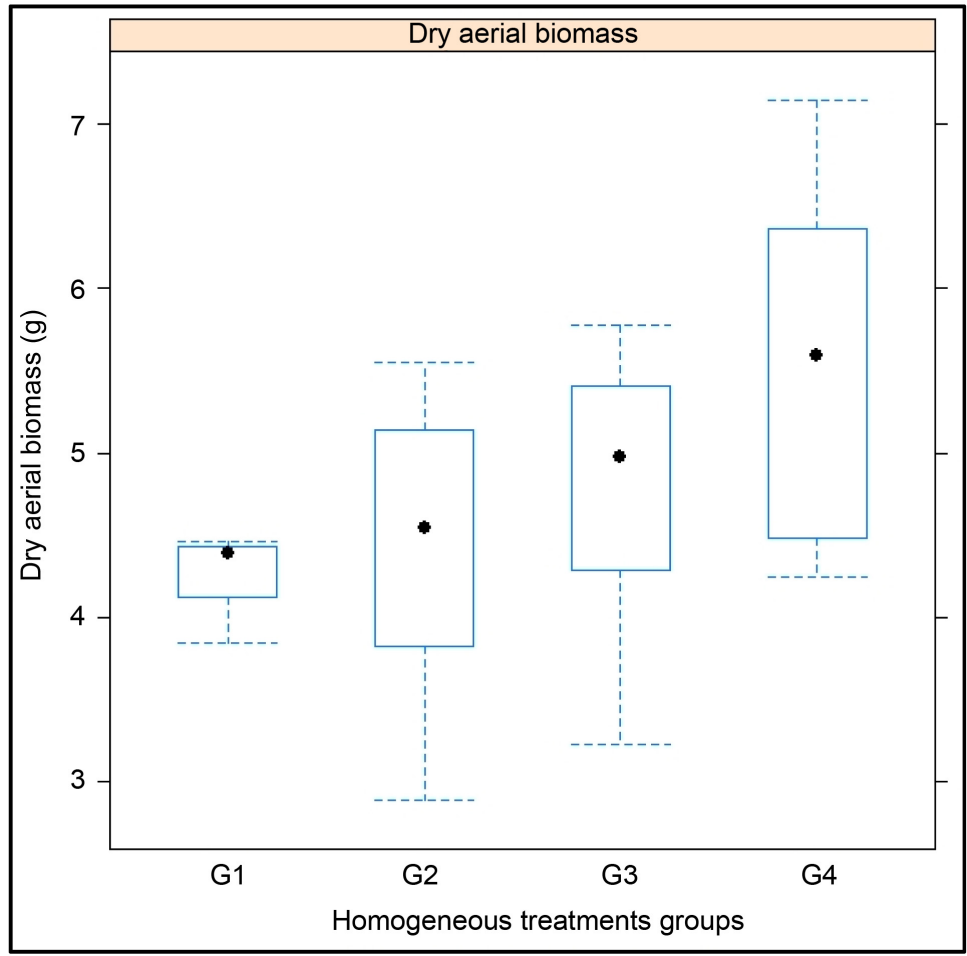

(b)

Figure 5. Effect of group treatments on production of dry aerial biomass (a) and dry underground biomass (b) of corn plants.

Pseudomonas fluorescens) significantly stimulated the dry weight of the aerial part of the $33.85 \%$ increase over controls, while the lowest dry aerial biomass 
was recorded at the control corn feet. Significant increases in the biomass of wheat plants and improved absorption of nutrients have also been reported by Emami et al. (2018) [46] with greenhouse inoculation of Pseudomonas strains characterized by multiple PGP activities. The results of the dry weight of plant biomass obtained in our study show that dry matter production has been improved by inoculation. El Fakhri et al. (2010) [47] reported that dry matter is used for the production of new roots, their proliferation (root volume), their lengthening (length growth) and their maintenance.

The classification obtained on the basis of the dendrogram (Figure 1(b)) shows that most individually tested strains, for example $P$. putida, $P$. cichorii, $P$. syringae, $B$. circulans, $B$. anthracisand $S$. marcescens, did not express a high capacity of stimulation for all the parameters assessed compared to the performance of the combinations of the so-called strains. On the other hand, the inoculation of $B$. thuringiensis induced very interesting effects comparable to those produced by $B$. thuringiensis, B. panthethonicus, $S$. marcescens, $P$. cichorii, $P$. putida, $P$. syringae and $P$. putida, B. thuringiensis, $S$. marcesens. Several studies have reported the ability to promote the growth of plants in greenhouses or in the field conditions of Bacillus strains, alone or in combination with other strains (Lim and Kim, 2009) [48] (Win et al., 2018) [49] Akinrinlola et al., 2018 [50]. Our results are consistent with those of Ishizawa et al. (2017) [51] who stated that the effect of combining different strains of PGPR was similar to the effect of individual strains on Lemna minor growth stimulation. On the other hand, the results obtained in our study are at odds with those reported by Yamakawa et al. (2018) [52]. The authors of this work noted that the effect of combining two strains of PGPR promoting lentucle growth was less than their mono-inoculation. Previous studies have previously reported the stimulation capacity of B. thuringiensis on various crop species (Goes, 2012) [53] (Raddadi etal., 2008) [54] because of its ability to produce metabolites of agricultural interest (Raddadi et al., 2008) [54]. This corroborates the results of work done in Canada by Emad et al. (2019) [55] which showed that R10 (B. thuringiensis) produced auxine (AIA), significantly improves the growth of Lemna Minor. Many authors have suggested that the effects of co-inoculation on plants depend on the particularity of the combinations used (Barea et al., 1998) [56] Molina-Romero et al., (2017) [57]. The work done by Agbodjato et al. (2018) [25] has demonstrated the ability of the majority of strains tested in our study to solubilize inorganic phosphate and produce metabolites of agricultural interest including acetic indole acid (AIA). The best results recorded on the parameters measured during our work would be related to the ability of PGPR strains to produce AIA, the siderophore, to solubilize phosphorus as it has been the case in many scientific works (Backer et al., 2018) [58] (Amogou et al., 2018) [59] (Won et al., 2019) [60].

\section{Conclusion}

PGPRs are used in agriculture as soil biofertilizers. These microorganisms have 
been shown to mediate interactions between plants and allow them to exploit soil resources. The results of this work confirm the importance of PGPR strains on height growth, neck diameter and dry weights of the aerial and underground portion of corn plants on depleted ferruginous soil in central Benin. Depending on whether combined or not, the best performance on the above parameters was recorded with $B$. thuringiensis, $B$. thuringiensis $B$. panthethonicus $S$. marcescens and Pseudomonas cichorii, Pseudomonas putida, and Pseudomonas syringae inoculation. Thus, the combined application of several strains of rhizobacteria to promote plant growth may have an effect comparable to that induced by mono-inoculation. These rhizobacteria presented desirable traits which might suggest promise for future field application to promote the growth of maize, thus contributing to sustainable agricultural practices in Benin.

\section{Acknowledgements}

Authors extend their thanks to the West Africa Agricultural Productivity Program (WAAPP/PPAAO), the "Centre National de Spécialisationsur le Maïs (CNS-Maïs)" and the "Fond National pour la Recherche Scientifique et de l'Innovation Technologique (FNRSIT)" of the Benin government for funding this project.

\section{Conflicts of Interest}

The authors declare that the research was conducted in the absence of any commercial or financial relationships that could be construed as a potential conflict of interest.

\section{References}

[1] Compant, S., Clément, C. and Sessitsch, A. (2010) Plant Growth-Promoting Bacteria in the Rhizo and Endosphere of Plants: Their Role, Colonization, Mechanisms Involved and Prospects for Utilization. Soil Biology and Biochemistry, 42, 669-678. https://doi.org/10.1016/j.soilbio.2009.11.024

[2] Beneduzi, A., Moreira, F., Costa, P.B., Vargas, L.K., Lisboa, B.B., Favreto, R., Baldani, J.I. and Passaglia, L.M.P. (2013) Diversity and Plant Growth Promoting Evaluation Abilities of Bacteria Isolated from Sugarcane Cultivated in the South of Brazil. Applied Soil Ecology, 63, 94-104. https://doi.org/10.1016/j.apsoil.2012.08.010

[3] Vale, M., Seldin, L., Araújo, F.F. and Lima, R. (2010) Plant Growth Promoting Rhizobacteria: Fundamentals and Applications. In: Maheshwari, D.K., Ed., Plant Growth and Health Promoting Bacteria, Springer, Berlin, 21-43. https://doi.org/10.1007/978-3-642-13612-2_2

[4] Wani, P.A., Khan, M.S. and Zaidi, A. (2007) Co-Inoculation of Nitrogen-Fixing and Phosphate Solubilizing Bacteria to Promote Growth, Yield and Nutrient Uptake in Chickpea. Acta Agronomica Hungarica, 55, 315-323.

https://doi.org/10.1556/AAgr.55.2007.3.7

[5] Martínez-Viveros, O., Jorquera, M., Crowley, D., Gajardo, G. and Mora, M. (2010) Mechanisms and Practical Considerations Involved in Plant Growth Promotion by Rhizobacteria. Journal of Soil Science and Plant Nutrition, 10, 293-319. https://doi.org/10.4067/S0718-95162010000100006 
[6] Vessey, J.K. (2003) Plant Growth Promoting Rhizobacteria as Biofertilizers. Plant and Soil, 255, 571-586. https://doi.org/10.1023/A:1026037216893

[7] Canbolat, M.Y., Bilen, S., Çakmakçı, R., Sahin, F. and Aydın, A. (2006) Effect of Plant Growth-Promoting Bacteria and Soil Compaction on Barley Seedling Growth, Nutrient Uptake, Soil Properties and Rhizosphere Microflora. Biology and Fertility of Soils, 42, 350-357. https://doi.org/10.1007/s00374-005-0034-9

[8] Goswami, D., Vaghela, H., Parmar, S., Dhandhukia, P. and Thakker, J.N. (2013) Plant Growth Promoting Potentials of Pseudomonas spp. Strain OG Isolated from Marine Water. Journal of Plant Interactions, 8, 281-290. https://doi.org/10.1080/17429145.2013.768360

[9] Bhattacharyya, P. and Jha, D. (2012) Plant Growth Promoting Rhizobacteria (PGPR): Emergence in Agriculture. World Journal of Microbiology and Biotechnology, 28, 1327-1350. https://doi.org/10.1007/s11274-011-0979-9

[10] Antoun, H. and Prevost, D. (2005) Ecology of Plant Growth Promoting Rhizobacteria. In: Siddiqui, Z.A., Ed., PGPR: Biocontrol and Biofertilization, Springer, Berlin, 1-38. https://doi.org/10.1007/1-4020-4152-7_1

[11] Rodríguez, H. and Fraga, R. (1999) Phosphate Solubilizing Bacteria and Their Role in Plant Growth Promotion.

[12] Peoples, M.B. and Craswell, E.T. (1992) Biological Nitrogen Fixation: Investments, Expectations and Actual Contribution to Agriculture. Plant and Soil, 141, 13-40. https://doi.org/10.1007/978-94-017-0910-1_2

[13] Gupta, R., Mathimaran, N., Wiemken, A., Boller, T., Bisaria, V.S. and Sharma, S. (2014) Non-Target Effects of Bioinoculants on Rhizospheric Microbial Communities of Cajanuscajan. Applied Soil Ecology, 76, 26-33. https://doi.org/10.1016/j.apsoil.2013.12.001

[14] Igué, A.M., Saïdou, A., Adjanohoun, A., Ezui, G., Attiogbé, P., Kpagbin, G., GotoechanHodonou, H., Youl, S., Pare, T., Balogoun, I., Ouedraogo, J., Dossa, E., Mando, A. and Sogbedji, J.M. (2013) Evaluation de la fertilité des sols au sud et centre du Bénin. Bulletin de la Recherche Agronomique du Bénin (BRAB) Numéro Spécial Fertilité du maïs-Janvier.

[15] Glick, B.R. (2010) Using Soil Bacteria to Facilitate Phytoremediation. Biotechnology Advances, 28, 367-374. https://doi.org/10.1016/j.biotechadv.2010.02.001

[16] Nabti, E., Bensidhoum, L., Tabli, N., Dahel, D., Weiss, A., Rothballer, M., Schmid, M. and Hartmann, A. (2014) Growth Stimulation of Barley and Biocontrol Effect on Plant Pathogenic Fungi by a Cellulosimicrobium sp. Strain Isolated from Salt-Affected Rhizosphere Soil in Northwestern Algeria. European Journal of Soil Biology, 61, 20-26. https://doi.org/10.1016/j.ejsobi.2013.12.008

[17] Adjanohoun, A., Noumavo, P.A., Sikirou, R., Allagbé, M., Gotoe-chan-Hodonou, H., Dossa, K.K., Yèhouénou, B., GlèlèKakaï, R. and Baba-Moussa, L. (2012) Effets des rhizobactéries PGPR sur le rendement et les teneurs en ma-croéléments du maïs sur sol ferralitique non dégradé au Sud-Bénin. International Journal of Biological and Chemical Sciences, 6, 279-288. https://doi.org/10.4314/ijbcs.v6i1.24

[18] Amogou, O., Dagbénonbakin, G., Agbodjato, N.A., Noumavo, P.A., Salako, K.V., Adoko, M.Y., Kakaï, R.G., Adjanohoun, A. and Baba-Moussa, L. (2019) Applying Rhizobacteria on Maize Cultivation in Northern Benin: Effect on Growth and Yield. Agricultural Sciences, 10, 763-782. https://doi.org/10.4236/as.2019.106059

[19] Cakamackci, R., Dönmez, M.F. and Erdogan, Ü. (2007) The Effect of Plant Growth Promotes Rhizobacteria on Barely Seedling Growth, Nutrient Uptake, Sum Soil Properties, and Bacterial Counts. Turkish Journal of Agriculture and Forestry, 31, 
189-199.

[20] Abaid-Ullah, M., Hassan, M.N., Jamil, M., Brader, G., Shah, M.K.N. and Sessitsch, A. (2015) Plant Growth Promoting Rhizobacteria: An Alternate Way to Improve Yield and Quality of Wheat (Triticum aestivum). International Journal of Agriculture and Biology, 17, 51-60.

[21] Egamberdiyeva, D. (2007) The Effect of Plant Growth Promoting Bacteria on Growth and Nutrient Uptake of Maize in Two Different Soils. Applied Soil Ecology, 36, 184-189. https://doi.org/10.1016/j.apsoil.2007.02.005

[22] Dicko, A.H., Babana, A.H., Kassogué, A., Fané, R., Nantoum, D., Ouattara, D., Maiga, K. and Dao, S. (2018) A Malian Native Plant Growth Promoting Actinomycetes Based Biofertilizer Improves Maize Growth and Yield. Springer Science + Business Media B.V., Berlin. https://doi.org/10.1007/s13199-018-0555-2

[23] Yallou, C.G., Aihou, K., Adjanohoun, A., Baco, M.N., Sanni, O.A. and Amadou, L. (2010) Répertoire des Variétés de Maïs Vulgarisées au Bénin: Document Technique d'Information et de vulgarisation. Dépôt légal $\mathrm{N}^{\circ} 4920,4 \mathrm{e}$ Trimestre, Bibliothèque Nationale du Bénin, 19 p.

[24] Agbodjato, N.A., Noumavo, P.A., Baba-Moussa, F., Salami, H.A., Sina, H., Sezan, A., Bankole, H., Adjanohoun, A. and Baba-Moussa, L. (2015) Characterization of Potential Plant Growth Promoting Rhizobacteria Isolated from Maize (Zea mays L.) in Central and Northern Benin (West Africa). Applied and Environmental Soil Science, 2015, Article ID: 901656. https://doi.org/10.1155/2015/901656

[25] Agbodjato, N.A., Amogou, O., Noumavo, P.A, Dagbenonbakin, G., Hafiz, A.S., Kamirou, R., Alladé, A.M., Adebayo, O., Baba-Moussa, F., Adjanohoun, A. and Ba-ba-Moussa, L. (2018) Biofertilising, Plant-Stimulating and Biocontrol Potentials of Isolated PGPR Rhizobacteria in Central and Northern Benin. African Journal of Microbiology Research, 12, 664-672. https://doi.org/10.5897/AJMR2018.8916

[26] Wahyudi, A.T., Astuti, R.P., Widyawati, A., Meryandini, A. and Nawangsih, A.A. (2011) Characterization of Bacillus sp. Strains Isolated from Rhizosphere of Soybean Plants for Their Use as Potential Plant Growth for Promoting Rhizobacteria. Journal of Microbiology and Antimicrobials, 3, 34-40.

[27] Aparna, Y. and Sarada, J. (2012) Molecular Characterization and Phylogenetic Analysis of Serratiasp-YAJS: An Extracellular Dnase Producer Isolated from Rhizosphere Soil.

[28] Govindappa, M.R.V., Ravishankar, S. and Lokesh (2011) Screening of Pseudomonas Fluorescens Isolates for Biological Control of Macrophomina phaseolina Root-Rot of Safflower. African Journal of Agricultural Research, 6, 6256-6266. https://doi.org/10.5897/AJAR10.1017

[29] Gholami, A., Shahsavani, S. and Nezarat, S. (2009) The Effect of Plant Growth Promoting Rhizobacteria (PGPR) on Germination, Seedling Growth and Yield of Maize. World Academy of Science, Engineering and Technology, 3, 1-14. https://doi.org/10.3923/pjbs.2009.26.32

[30] Assogba, S., Noumavo, P.A., Dagbenonbakin, G., Nadège Agbodjato, N.A., Akpode, C., Koda, A.D., Aguegue, R.M., Bade, F., AdolpheAdjanohoun, A., et al. (2017) Improvement of Maize Productivity (Zea mays L.) by Mycorrhizal Inoculation on Ferruginous Soil in Center of Benin. International Journal of Sustainable Agricultural Research, 4, 63-76.

[31] Etèka, A.C. (2005) Comtribution des jachères manioc dans l'amélioration du rendement des cultures et du prélèvement des nutriments: Cas de la succession culturale manioc-maïs au Centre du Bénin. Thèse de DEA, FSA/UAC, Bénin, 107 p. 
[32] Ruget, F. and Bonhomme, C.M. (1996) Estimation Simple de la surface foliaire de plantes de maïs en croissance. Agronomie, 16, 553-562. https://doi.org/10.1051/agro:19960903

[33] Bidogeza, J.C., Berentsen, B.P.M., De Graaff, J. and Oude-Lansink, A.G.J.M. (2009) A Typology of Farm Households for the Umutara Province in Rwanda. Food Science, 1, 321-335. https://doi.org/10.1007/s12571-009-0029-8

[34] R Core Team (2019) R: A Language and Environment for Statistical Computing. R Foundation for Statistical Computing, Vienna.

[35] GlèlèKakaï, R., Sodjinou, E. and Fonton, H.N. (2006) Conditions d'Application des Méthodes Statistiques Paramétriques, Bibliothèque Nationale, Bénin.

[36] Qaisrani, M.M., Mirza, M.S., Zaheer, A. and Malik, K.A. (2014) Isolation and Identification by 16s rRNA Sequence Analysis of Achromobacter, Azospirillum and Rhodococcus Strains from the Rhizosphere of Maize and Screening for the Beneficial Effect on Plant Growth. Pakistan Journal of Agricultural Sciences, 51, 91-99.

[37] Karnwal, A. (2017) Isolation and Identification of Plant Growth Promoting Rhizobacteria from Maize (Zea mays L.) Rhizosphere and Their Plant Growth Promoting Effect on Rice (Oryza sativa L.). Journal of Plant Protection Research, 57, 144-151. https://doi.org/10.1515/jppr-2017-0020

[38] Noumavo, P.A., et al. (2013) Effect of Different Plant Growth Promoting Rhizobacteria on Maize Seed Germination and Seedling Development. American Journal of Plant Sciences, 4, 1013-1021. https://doi.org/10.4236/ajps.2013.45125

[39] Emami, S., Alikhani, H.A., Pourbabaei, A.A., Etesami, H., Sarmadian, F. and Motessharezadeh, B. (2019) Effect of Rhizospheric and Endophytic Bacteria with Multiple Plant Growth Promoting Traits on Wheat Growth. Environmental Science and Pollution Research, 26, 19804-19813. https://doi.org/10.1007/s11356-019-05284-X

[40] Duponnois, R., Founoune, H., Masse, D. and Pontanier, R. (2005) Inoculation of Acacia Endophytes in Zea across Boundaries of Evolution, Ethnography and Ecology.

[41] Biaou, G. and Gnimadi, C. (2012) Étude socio-économique de synthèse des villages de Founougo_A, Founougo_B et Kanderou. Rapport provisoire pour le "Projet d'Appui à l'Opérationnalisation des Villages du Millénaire" (PVM) 150.

[42] Salantur, A., Ozturk, A. and Akten, S. (2006) Growth and Yield Response of Spring Wheat (Triticum aestivum L.) to Inoculation with Rhizobacteria. Plant and Soil Environment, 52, 111-118. https://doi.org/10.17221/3354-PSE

[43] Nandakumar, R., Babu, S., Viswanathan, R., Sheela, J., Raguchander, T. and Samiyappan, R. (2001) A New Bio-Formulation Containing Plant Growth Promoting Rhizobacterial Mixture for the Management of Sheath Blight and Enhanced Grain Yield in Rice. BioControl, 46, 493-510. https://doi.org/10.1023/A:1014131131808

[44] Oluwambe, T.M. and Kofoworola, A.A. (2016) Comparison of Single Culture and the Consortium of Growth-Promoting Rhizobacteria from Three Tomato (Lycopersicon esculentum Mill) Varieties. APAR, 5, 448-455. https://doi.org/10.15406/apar.2016.05.00167

[45] Akhtar, N., Naveed, M., Khalid, M., Ahmad, N., Rizwan, M. and Siddique, S. (2018) Effect of Bacterial Consortia on Growth and Yield of Maize Grown in Fusarium Infested Soil. Soil \& Environment, 37, 35-44. https://doi.org/10.25252/SE/18/872

[46] Emami, S., Alikhani, H.A., Pourbabaei, A.A., Etesami, H., MotashareZadeh, B. and Sarmadian, F. (2018) Improved Growth and Nutrient Acquisition of Wheat Geno- 
types in Phosphorus Deficient Soils by Plant Growth-Promoting Rhizospheric and Endophytic Bacteria. Soil Science and Plant Nutrition, 64, 719-727. https://doi.org/10.1080/00380768.2018.1510284

[47] El Fakhakhri, M., Mahboub, S., Benchekroun, M. and Nasrellah, N. (2010) Effet du stress hydrique sur la caractéristiques d'enracinement du blé dur (Triticum durum Desf). Nature et Technologie, 3, 6-12.

[48] Lim, J.-H. and Kim, S.-D. (2009) Synergistic Plant Growth Promotion by the Indigenous Auxins-Producing PGPR Bacillus subtilis AH18 and Bacillus licheniforims K11. Journal of the Korean Society for Applied Biological Chemistry, 52, 531-538. https://doi.org/10.3839/jksabc.2009.090

[49] Win, K.T., Oo, A.Z., Ohkama-Ohtsu, N. and Yokoyama, T. (2018) Bacillus Pumilus Strain TUAT-1 and Nitrogen Application in Nursery Phase Promote Growth of Rice Plants under Field Conditions. Agronomy, 8, 216.

https://doi.org/10.3390/agronomy8100216

[50] Akinrinlola, R.J., Yuen, G.Y., Drijber, R.A. and Adesemoye, A.O. (2018) Evaluation of Bacillus Strains for Plant Growth Promotion and Predictability of Efficacy by in Vitro Physiological Traits. International Journal of Microbiology, 2018, Article ID: 5686874. https://doi.org/10.1155/2018/5686874

[51] Ishizawa, H., Kuroda, M., Morikawa, M. and Ike, M. (2017) Evaluation of Environmental Bacterial Communities as a Factor Affecting the Growth of Duckweed Lemna Minor. Biotechnology for Biofuels, 10, 62. https://doi.org/10.1186/s13068-017-0746-8

[52] Yamakawa, Y., Jog, R. and Morikawa, M. (2018) Effects of Co-Inoculation of Two Different Plant Growth-Promoting Bacteria on Duckweed. Plant Growth Regulation, 86, 287-296. https://doi.org/10.1007/s10725-018-0428-y

[53] Goes, K.C.G.P. (2012) Biochemical and Molecular Characterization of High Population Density Bacteria Isolated from Sunflower. Journal of Microbiology and Biotechnology, 22, 437-447. https://doi.org/10.4014/jmb.1109.09007

[54] Raddadi, N., Cherif, A., Boudabous, A. and Daffonchio, D. (2008) Screening of Plant Growth Promoting Traits of Bacillus thuringiensis. Annals of Microbiology, 58, 47-52. https://doi.org/10.1007/BF03179444

[55] Emad, L. (2019) Promotion de la croissance des plantes en utilisant des souches de Streptomyces et de Bacillus produisant de l'auxine, seules ou en consortium. Mémoire de Master, Université de Sherbrooke, 96.

[56] Barea, J.M., Azcón-aguilar, C. and Azcón, R. (1997) Interactions between Mycorrhizal Fungi and Rhizosphere Microorganisms within the Context of Sustainable Soil-Plant Systems. In: Gange, A.C. and Brown, V.K., Eds., Multitrophic Interactions in Terrestrial Systems, Blackwell Science, Cambridge, 65-77.

[57] Molina-Romero, D., Baez, A., Quintero-Hernández, V., Castañeda-Lucio, M., Fuentes-Ramírez, L.E., Bustillos-Cristales, M.R., Rodríguez-Andrade, O., Morales-García, Y.E., Munive, A. and Muñoz-Rojas, J. (2017) Compatible Bacterial Mixture, Tolerant to Desiccation, Improves Maize Plant Growth. PLoS ONE, 12, e0187913. https://doi.org/10.1371/journal.pone.0187913

[58] Backer, R., Rokem, J.S., Ilangumaran, G., Lamont, J., Praslickova, D., Ricci, E., Subramanian, S. and Smith, D.L. (2018) Plant Growth-Promoting Rhizobacteria: Context, Mechanisms of Action, and Roadmap to Commercialization of Biostimulants for Sustainable Agriculture. Frontiers in Plant Science, 9, 1473. https://doi.org/10.3389/fpls.2018.01473

[59] Amogou, O., Dagbénonbakin, G., Agbodjato, N.A., Noumavo, P.A., Salami, H.A., 
Valère, S., Ricardos, A.M., Sylvestre, A.A., Djihal, K.F.A., Adjanohoun, A. and Baba-Moussa, L. (2018) Influence of Isolated PGPR Rhizobacteria in Central and Northern Benin on Maize Germination and Greenhouse Growth. American Journal of Plant Sciences, 9, 2775-2793. https://doi.org/10.4236/ajps.2018.913201

[60] Won, S.J., Kwon, J.H., Kim, D.H. and Ahn, Y.S. (2019) The Effect of Bacillus licheniformis MH48 on Control of Foliar Fungal Diseases and Growth Promotion of Camellia oleifera Seedlings in the Coastal Reclaimed Land of Korea. Pathogens, 8, 6. https://doi.org/10.3390/pathogens 8010006 